\title{
PENERAPAN MODEL PEMBELAJARAN KOOPERATIF TEAM ASSISTED INDIVIDUALIZATION (TAI) DILENGKAPI LKS UNTUK MENINGKATKAN KEMAMPUAN BERPIKIR KRITIS DAN PRESTASI BELAJAR SISWA PADA MATERI KELARUTAN DAN HASIL KALI KELARUTAN KELAS XI IPA 3 SMA NEGERI 2 BOYOLALI TAHUN PELAJARAN 2015/2016
}

\author{
Desy Ratna Sari ${ }^{\star}$, Mohammad Masykuri, dan Sri Mulyani \\ Program Studi Pendidikan Kimia, FKIP,Universitas Sebelas Maret, Surakarta, Indonesia \\ *Keperluan korespondensi, telp: 085602176786, email: ratnadesy68@gmail.com
}

\begin{abstract}
ABSTRAK
Penelitian ini bertujuan untuk mengetahui peningkatan kemampuan berpikir kritis dan prestasi belajar siswa melalui penerapan model pembelajaran kooperatif Team Assisted Individualization (TAI) dilengkapi LKS pada materi pokok kelarutan dan hasil kali kelarutan di SMA Negeri 2 Boyolali. Penelitian ini merupakan penelitian tindakan kelas (PTK) yang dilaksanakan dalam 2 siklus. Tiap siklus terdiri atas perencanaan, pelaksanaan tindakan, observasi, dan refleksi. Subjek penelitian adalah siswa kelas XI IPA 3 SMA Negeri 2 Boyolali tahun pelajaran 2015/2016. Teknik pengumpulan data melalui observasi, wawancara, tes, angket, dan dokumentasi. Validasi data menggunakan teknik triangulasi. Hasil penelitian menunjukkan bahwa penerapan model pembelajaran kooperatif Team Assisted Individualization (TAI) dilengkapi LKS dapat meningkatkan kemampuan berpikir kritis dan prestasi belajar siswa pada materi pokok kelarutan dan hasil kali kelarutan di SMA Negeri 2 Boyolali. Persentase kemampuan berpikir kritis meningkat dari $32,35 \%$ pada prasiklus menjadi $70,59 \%$ pada siklus I. Persentase ketuntasan belajar kognitif siswa pada siklus I adalah $55,88 \%$ meningkat menjadi $82,35 \%$ pada siklus II, sedangkan persentase capaian afektif pada siklus I adalah $91,17 \%$ meningkat menjadi $100 \%$ pada siklus II.
\end{abstract}

Kata kunci: Team Assisted Individualization (TAI), kemampuan berpikir kritis, prestasi belajar, kelarutan dan hasil kali kelarutan

\section{PENDAHULUAN}

Masalah pendidikan menjadi perhatian serius bagi bangsa Indonesia mengingat pentingnya peranan pendidikan dalam kemajuan bangsa. Salah satu masalah yang dihadapi dunia pendidikan kita adalah lemahnya proses pembelajaran. Dalam proses pembelajaran, siswa tidak didorong untuk mengembangkan kemampuan berpikir, memecahkan masalah, serta potensi yang dimiliki, melainkan hanya diarahkan untuk mengingat dan menimbun informasi tanpa dituntut untuk menghubungkan informasi tersebut dalam kehidupan sehari-hari. Akibatnya, siswa hanya pintar secara teoritis tetapi miskin aplikasi dan tujuan pendidikan tidak tercapai. Berbagai upaya yang telah dilakukan pemerintah untuk mengatasi permasalahan diatas antara lain melakukan perubahan kurikulum, peningkatan kualitas guru, penerapan model pembelajaran yang sesuai dengan karakter siswa, dan penyediaan sarana dan prasarana sekolah [1].

Salah satu komponen terpenting dalam sistem pendidikan di Indonesia adalah kurikulum. Saat ini, ada dua kurikulum yang digunakan yaitu KTSP dan Kurikulum 2013. Adapun kurikulum yang digunakan dalam penelitian ini adalah KTSP. Kurikulum Tingkat Satuan Pendidikan (KTSP) adalah kurikulum operasional yang disusun dan dilaksana- 
kan di masing-masing satuan pendidikan. Pada implementasi kurikulum ini, siswa tidak lagi menjadi obyek melainkan sebagai subyek yang belajar sesuai dengan bakat, minat dan kemampuan yang dimilikinya, sehingga paradigma pembelajaran yang berpusat pada guru harus diubah menjadi pembelajaran yang berpusat pada siswa [2].

Salah satu materi kimia SMA yang mengandung konsep-konsep yang bersifat abstrak dan perhitungan adalah kelarutan dan hasil kali kelarutan. Pada materi tersebut terdapat beberapa konsep seperti, kesetimbangan larutan jenuh, kelarutan, ion senama, dan lain-lain. Konsep-konsep tersebut bersifat abstrak sebab berhubungan dengan ion, molekul dan reaksi kesetimbangan yang tidak dapat diamati oleh mata. Materi kelarutan dan hasil kali kelarutan juga mengandung konsep-konsep yang pemahamannya membutuhkan perhitungan, misalnya menghitung kelarutan, Ksp dan membandingkan nilai Ksp dengan Qsp [3].

Berdasarkan hasil wawancara dengan guru kimia di SMA Negeri 2 Boyolali pada tangal 5 Januari 2016, materi kelarutan dan hasil kali kelarutan dirasakan sulit bagi siswa. Kesulitan siswa pada materi kelarutan dan hasil kali kelarutan juga dibuktikan dari data ulangan harian siswa tahun pelajaran 2014/2015 yang ditunjukkan dalam Tabel 1.

\section{Tabel 1. Ketuntasan Materi Kelarutan dan Hasil Kali Kelarutan Berdasarkan Nilai Ulangan Harian Kelas XI IPA SMA Negeri 2 Boyolali Tahun Pelajaran 2014/2015}

\begin{tabular}{ccc}
\hline Kelas & KKM & $\begin{array}{c}\text { Ketuntasan } \\
(\%)\end{array}$ \\
\hline XI IPA 1 & 76 & 23,07 \\
XI IPA 2 & 76 & 26,92 \\
XI IPA 3 & 76 & 26,92 \\
XI IPA 4 & 76 & 42,30 \\
XI IPA 5 & 76 & 36,00 \\
\hline
\end{tabular}

SMA Negeri 2 Boyolali memiiki lima kelas untuk progam IPA. Dari kelima kelas tersebut sebagian besar memiliki prestasi belajar yang rendah. Hal ini terlihat dari nilai ulangan akhir semester ganjil siswa kelas XI IPA Tahun Pelajaran 2015/2016 yang ditunjukkan pada Tabel 2.

Tabel 2. Ketuntasan Mata Pelajaran Kimia Berdasarkan Nilai Ulangan Akhir Semester Kelas XI IPA SMA Negeri 2 Boyolali Tahun Pelajaran 2015/2016

\begin{tabular}{cccc}
\hline Kelas & KKM & $\begin{array}{c}\text { Rata- } \\
\text { rata }\end{array}$ & $\begin{array}{c}\text { Ketuntasan } \\
(\%)\end{array}$ \\
\hline XI IPA 1 & 76 & 62,92 & 2,85 \\
XI IPA 2 & 76 & 62,70 & 0 \\
XI IPA 3 & 76 & 62,25 & 0 \\
XI IPA 4 & 76 & 62,40 & 0 \\
XI IPA 5 & 76 & 62,55 & 0 \\
\hline
\end{tabular}

Dari Tabel 2 menunjukkan bahwa kelas XI IPA 3 memiliki nilai rata-rata kelas yang paling rendah yaitu sebesar 62,25. Hal itu didukung dari hasil observasi bahwa dalam proses pembelajaran masih menggunakan metode konvensional yaitu ceramah yang menjadikan guru sebagai pusat kegiatan belajar mengajar. Aktivitas siswa hanya mendengarkan, mencatat pelajaran dan mengerjakan soal yang diberikan guru. Akibat dari kebiasaan tersebut siswa menjadi kurang aktif dalam memecahkan masalah, partisipasi rendah dan aktivitas kelompok rendah, selain itu ketika siswa diberi soal dengan tipe berbeda siswa tidak dapat menentukan informasi dan masalah apa yang terdapat dalam soal. Siswa cenderung hanya menghafal rumus dan bentuk soal. Siswa kurang memiliki kemampuan dalam memecahkan soal yang melibatkan penggabungan konsep-konsep yang sudah dipelajari, pengoperasian hitung matematik dan logika.

Dari hasil tes kemampuan berpikir kritis pada prasiklus menunjukkan sebanyak 32,35\% siswa berkategori kemampuan berpikir kritis tinggi, 35,29\% siswa berkategori kemampuan berpikir kritis sedang, dan $32,35 \%$ siswa berkategori kemampuan berpikir kritis rendah. Berdasarkan uraian di atas, maka dapat disimpulkan bahwa permasalahan pembelajaran yang terjadi di kelas XI IPA 3 adalah rendahnya 
kemampuan berpikir kritis dan prestasi belajar siswa.

Kemampuan berpikir kritis merupakan sebuah proses yang terarah dan jelas yang digunakan dalam kegiatan mental seperti memecahkan masalah, mengambil keputusan, membujuk, menganalisis informasi, dan melakukan penelitian ilmiah [4]. Berdasarkan dari penelitian Hashemi, pembelajaran dengan memperhatikan kemampuan berpikir kritis dapat memberikan hasil yang baik pada perkembangan kognitif, moral, sosial, mental serta perkembangan sains [5]. Oleh karena itu, kemampuan berpikir kritis merupakan salah satu faktor penting yang mempengaruhi tingkat penguasaan materi pelajaran terutama kompetensi kelarutan dan hasil kali kelarutan (Ksp) yang memerlukan pemahaman konsep yang kuat dan hitungan matematis.

Berbagai permasalahan tersebut merupakan masalah di dalam suatu proses pembelajaran yang dapat diselesaikan dengan Penelitian Tindakan Kelas (PTK) atau Classroom Action Research (CAR). Oleh karena itu, tindakan yang dapat dilakukan untuk menyelesaikan permasalahan ini adalah melalui penggunaan model pembelajaran yang dapat meningkatkan kemampuan berpikir kritis maupun prestasi belajar siswa kelas XI IPA 3 SMA Negeri 2 Boyolali, khususnya pada materi kelarutan dan hasil kali kelarutan.

Model pembelajaran yang sesuai untuk meningkatkan kemampuan berpikir kritis dan prestasi belajar siswa yaitu dengan menerapkan model pembelajaran kooperatif. Penerapan pembelajaran kooperatif akan mempermudah siswa untuk menemukan dan memahami konsep-konsep yang sulit apabila siswa dapat saling mendiskusikan masalahmasalah yang dihadapi dengan temannya. Hal itu didukung penelitian dari Slavin yang menyatakan bahwa, pembelajaran kooperatif dapat me-ningkatkan prestasi belajar siswa dan dapat merealisasikan kebutuhan siswa dalam belajar berpikir kritis [1]. Hasil Penelitian Nezami,dkk. menyatakan bahwa pembelajaran kooperatif dapat meningkatkan kemampuan berpikir kritis siswa [6].
Salah satu model pembelajaran kooperatif adalah model pembelajaran Team Assisted Individualization (TAI). Model pembelajaran TAI merupakan model pembelajaran secara kelompok dengan seorang siswa yang lebih pandai berperan sebagai asisten yang bertugas membantu secara individual siswa lain yang kurang pandai dalam kelompok itu. Dalam hal ini, peran pendidik hanya sebagai fasilitator dan mediator dalam proses belajar mengajar. Unsur dalam TAI yang diperkirakan dapat meningkatkan kemampuan berpikir kritis adalah saat siswa mengidentifikasi dan menganalisis informasi untuk memecahkan masalah dengan saling bertukar pendapat dalam diskusi kelompok. Penerapan model TAI dalam proses pembelajaran memberikan kesempatan kepada siswa untuk mengkonstruksikan sendiri kemampuannya, sehingga semua siswa mendapat kesempatan yang merata untuk dapat berpartisipasi aktif dalam pembelajaran [7], selain itu penerapan model TAl sangat efektif untuk meningkatkan prestasi belajar matematika [8].

Penerapan model pembelajaran kooperatif TAl dalam proses pembelajaran perlu ditunjang dengan media pembelajaran salah satunya LKS. LKS merupakan lembar-lembar kertas yang berisi materi, ringkasan dan petunjukpetunjuk pelaksanaan tugas pembelajaran yang harus dikerjakan oleh siswa yang mengacu pada kompetensi dasar yang harus dicapai [9]. Penggunaan LKS ini dipilih karena materi kelarutan dan hasl kali kelarutan mengandung banyak konsep-konsep dan hitungan yang rumit. Dengan digunakannya LKS diharapkan siswa dapat termotivasi untuk meningkatkan prestasi belajar dengan memahami materi dan mengerjakan tugas-tugas yang ada di dalam LKS. Pembelajaran dengan LKS lebih efektif daripada kelas yang diajar dengan metode konvensional karena siswa ikut aktif dalam pembelajaran dan guru dapat menentukan target pembelajaran yang bisa dicapai melalui pembelajaran tersebut, selain itu pembelajaran dengan LKS dapat meningkatkan prestasi belajar siswa khususnya 
untuk materi kimia yang melibatkan konsep-konsep abstrak [10].

Berdasarkan latar belakang yang telah diuraikan di atas penulis merasa perlu untuk melakukan penelitian tentang "Penerapan Model Pembelajaran Kooperatif Team Assisted Individualization (TAI) dilengkapi LKS untuk Meningkatkan Kemampuan Berpikir Kritis dan Prestasi Belajar Siswa pada Materi Kelarutan dan Hasil Kali Kelarutan (Ksp) Kelas XI IPA 3 SMA Negeri 2 Boyolali Tahun Pelajaran 2015/2016".

\section{METODE PENELITIAN}

Penelitian ini merupakan Penelitian Tindakan Kelas (Classroom Action Research). Prosedur Penelitian Tindakan Kelas ini biasanya meliputi beberapa siklus, dimana penelitian ini dilaksanakan dua siklus. Prosedur yang digunakan dalam melaksanakan Penelitian Tindakan Kelas (PTK) ini berupa model spiral. Ada empat tahap dalam model spiral, yaitu perencanaan (planning), tindakan (acting), pengamatan (observing) dan refleksi (reflecting) [11].

Subjek penelitian adalah siswa kelas XI IPA 3 semester genap SMA Negeri 2 Boyolali tahun pelajaran 2015/2016 yang berjumlah 34 siswa. Pemilihan subjek dalam penelitian ini didasarkan pada pertimbangan bahwa subjek tersebut mengalami permasalahan yang telah teridentifikasi pada saat observasi awal. Objek penelitian ini adalah kemampuan berpikir kritis dan prestasi belajar siswa (kognitif dan afektif) terhadap pembelajaran yang diterapkan.

Data yang dikumpulkan dalam penelitian ini meliputi data informasi tentang keadaan siswa dilihat dari aspek kualitatif dan kuantitatif. Aspek kualitatif berupa data hasil observasi, wawancara, kajian dokumen dan pemberian angket yang menggambarkan proses pembelajaran di kelas. Aspek kuantitatif berupa tes kemampuan berpikir kritis dan prestasi belajar siswa pada materi Ksp yang meliputi aspek kognitif dan afektif untuk siklus I sedangkan untuk siklus II hanya prestasi belajar meliputi aspek kognitif dan afektif.
Analisis data dalam Penelitian Tindakan Kelas (PTK) dimulai sejak awal sampai berakhirnya pengumpulan data. Data-data dari hasil penelitian di lapangan diolah dan dianalisis secara kualitatif. Analisis kualitatif yang dimaksud adalah analisis deskriptif. Teknik analisis juga mengacu pada model analisis Miles dan Huberman yang dilakukan dalam tiga komponen yaitu reduksi data, penyajian data, penarikan kesimpulan dan verifikasi [12].

Teknik validitas data yang digunakan dalam penelitian ini adalah triangulasi. Triangulasi merupakan teknik pemeriksaan data yang memanfaatkan sesuatu yang lain diluar data itu untuk keperluan pengecekan atau pembanding terhadap data itu. Teknik triangulasi yang digunakan adalah triangulasi metode [13]. Dalam penelitian ini peneliti menggunakan metode pengumpulan data melalui teknik observasi, wawancara, kajian dokumen, angket dan tes.

\section{HASIL DAN PEMBAHASAN}

Dari data observasi awal tanggal 5 Januari 2016 menunjukkan proses pembelajaran masih berpusat pada guru, selain itu berdasarkan kajian dokumen menunjukkan bahwa penguasaan konsep siswa terhadap materi kelarutan dan hasil kali kelarutan masih rendah. Hal ini menyebabkan proses pembelajaran menjadi pasif. Padahal keterlibatan dan penguasaan konsep siswa dalam proses kegiatan belajar mengajar dapat dijadikan sebagai indikator keberhasilan dari kualitas pembelajaran yang dapat dilihat dari perolehan prestasi belajar dari siswa.

Salah satu faktor internal yang mempengaruhi tingkat penguasaan konsep adalah kemampuan berpikir kritis. Oleh karena itu, kemampuan berpikir kritis perlu dikembangkan dalam proses pembelajaran. Salah satu sarana yang digunakan untuk mengasah kemampuan ini melalui model pembelajaran kooperatif TAI. Unsur dalam TAl yang diperkirakan dapat meningkatkan kemampuan berpikir kritis adalah saat siswa mengidentifikasi dan menganalisis informasi untuk memecahkan 
masalah dengan saling bertukar pendapat dalam diskusi kelompok. Dengan meningkatnya kemampuan berpikir kritis maka kesulitan-kesulitan yang dialami oleh siswa terkait dengan materi akan dapat teratasi, sehingga prestasi belajar siswa dapat meningkat.

\section{Siklus I}

Pada tahap perencanaan, peneliti bersama guru menyiapkan silabus, RPP, media pembelajaran, instrumen penelitian, dan merencanakan jadwal penelitian. Pembelajaran direncanakan terdiri dari 11 jam pelajaran (6 kali tatap muka) yaitu 8 x 45 menit untuk penyampaian materi dan $3 \times 45$ menit untuk tes evaluasi siklus I.

\section{Berdasarkan perencanaan}

tindakan yang telah dilakukan oleh peneliti, kemudian diterapkan di kelas XI IPA 3 SMA Negeri 2 Boyolali. Proses pembelajaran menggunakan model Team Assisted Individualization (TAI), siswa dibagi menjadi 8 kelompok dengan masing-masing kelompok beranggotakan 4-5 orang dengan salah satu anggota sebagai asisten (Sintaks TAI no 1). Kemudian guru memberikan garis besar materi yang dipelajari (Sintaks TAI no 2). Siswa selanjutnya diberikan waktu untuk mempelajari materi secara individual (Sintaks TAl no 3). Siswa kemudian berdiskusi (Sintaks TAI no 4). Selanjutnya dilaksanakan latihan soal individual (Sintaks TAl no 5) dan penghargaan kelompok (Sintaks TAI no 6). Kemudian guru memberikan penekanan-penekanan mengenai konsep materi dan membimbing siswa membuat kesimpulan (Sintaks no 7)

Pada akhir siklus I dilakukan tes kemampuan berpikir kritis, tes kognitif dan pemberian angket afektif. Penilaian untuk aspek kognitif diperoleh ketuntasan sebanyak 19 siswa dari 34 siswa, sehingga persentase ketuntasan aspek pengetahuan siswa XI IPA 3 adalah $55,88 \%$. Penilaian aspek afektif menggunakan angket serta observasi. Hasil aspek afektif diperoleh presentase ketuntasan siswa XI IPA 3 adalah $91,17 \%$. Penilaian untuk aspek kemampuan berpikir kritis siswa menggunakan tes. Hasil tes kemampuan berpikir kritis diperoleh persentase ketuntasan sebesar 70,59\%. Ketercapaian masing-masing aspek pada siklus I disajikan dalam Tabel 3.

Tabel 3. Keberhasilan Siklus I Materi Kelarutan dan Hasil Kali Kelarutan Kelas XI IPA 3 SMA Negeri 2 Boyolali Tahun Pelajaran 2015/2016

\begin{tabular}{lccl}
\hline \multirow{2}{*}{ Aspek } & \multicolumn{2}{c}{ Siklus I (\%) } & \\
\cline { 2 - 3 } & $\begin{array}{c}\text { Capai- } \\
\text { an }\end{array}$ & Target & Kriteria \\
\hline $\begin{array}{l}\text { Kemam- } \\
\text { puan } \\
\text { berpikir } \\
\text { kritis }\end{array}$ & 70,59 & 55 & Tercapai \\
Kognitif & 55,88 & 75 & $\begin{array}{l}\text { Belum } \\
\text { Tercapai }\end{array}$ \\
Afektif & 91,17 & 75 & Tercapai \\
\hline
\end{tabular}

Berdasarkan Tabel 3 terlihat bahwa prestasi belajar kognitif belum mencapai target, sehingga perlu dilakukan perbaikan di siklus II, sedangkan untuk aspek afektif sudah mencapai target siklus I namun tetap dilaksanakan siklus II untuk memenuhi target indikatorindikator yang belum tercapai serta untuk mengetahui besar peningkatannya. Untuk aspek kemampuan berpikir kritis sudah mencapai target, sehingga tidak diperlukan perbaikan di siklus II.

\section{Siklus II}

Berdasarkan dari hasil refleksi tindakan siklus I maka dilakukan perencanaan untuk pelaksanaan tindakan pada siklus II. Pada pembelajaran siklus II difokuskan pada indikator kompetensi yang belum tercapai. Guru mengulang kembali indikator kompetensi pada aspek kognitif yang belum tuntas, yaitu menghubungkan tetapan hasil kali kelarutan dengan kelarutan, menghitung $\mathrm{pH}$ larutan dari harga Ksp atau sebaliknya dan menghitung Ksp berdasarkan harga $\mathrm{pH}$ terjadinya endapan atau sebaliknya. Asisten di siklus II dipilih berdasarkan nilai terbaik saat siklus I dan dibantu teman yang sudah tuntas, sehingga masingmasing kelompok terdapat 1 asisten dan 1-2 siswa yang sudah tuntas.

Pada pertemuan terakhir siklus II dilakukan tes kognitif dan pengisian 
angket afektif. Hasil tes kognitif siklus II diperoleh persentase ketuntasan siswa sebesar $82,35 \%$, sedangkan aspek afektif sebesar $100 \%$. Hasil dari aspek kognitif sudah mencapai target yang ditetapkan, sedangkan aspek afektif siswa mengalami peningkatan. Ketercapaian masing-masing aspek di siklus II disajikan dalam Tabel 4.

Tabel 4. Keberhasilan Siklus II Materi Kelarutan dan Hasil Kali Kelarutan Kelas IPA 3 SMA Negeri 2 Boyolali Tahun Pelajaran 2015/2016

\begin{tabular}{cccc}
\hline \multirow{2}{*}{ Aspek } & \multicolumn{2}{c}{ Siklus II (\%) } & \multirow{2}{*}{ Kriteria } \\
\cline { 2 - 3 } & Capaian & Target & \\
\hline Kognitif & 82,35 & 75 & Berhasil \\
Afektif & 100 & 75 & Berhasil \\
\hline
\end{tabular}

\section{Perbandingan antar Siklus}

Perbandingan hasil tindakan antar siklus ini bertujuan untuk mengetahui peningkatan yang terjadi selama tindakan siklus I dan siklus II. Perbandingan hasil tindakan antar siklus yang disajikan dalam Tabel 5 .

Tabel 5. Perbandingan Hasil Tindakan antar Siklus Materi Kelarutan dan Hasil Kali Kelarutan Kelas IPA 3 SMA Negeri 2 Boyolali Tahun Pelajaran 2015/2016

\begin{tabular}{|c|c|c|c|}
\hline \multirow[b]{2}{*}{ Aspek } & \multicolumn{2}{|c|}{ Capaian (\%) } & \multirow[b]{2}{*}{ Kriteria } \\
\hline & 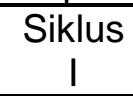 & $\underset{I I}{\text { Siklus }}$ & \\
\hline Kognitif & 32,35 & 82,35 & Berhasil \\
\hline Afektif & 91,17 & 100 & Berhasil \\
\hline
\end{tabular}

Berdasarkan Tabel 5 diatas dapat dilihat bahwa terjadi adanya peningkatan dari siklus I ke siklus II. Aspek kognitif pada siklus II dapat mencapai target yang diinginkan, sedangkan untuk aspek afektif meningkat di siklus II. Dalam penelitian tindakan kelas, suatu penelitian dinyatakan berhasil apabila masing-masing aspek yang diukur telah mencapai target yang telah ditetapkan.

\section{KESIMPULAN}

Model pembelajaran kooperatif Team Assisted Individualization (TAI) dilengkapi LKS dapat meningkatkan kemampuan berpikir kritis dan prestasi belajar siswa pada materi kelarutan dan hasil kali kelarutan kelas XI IPA 3 SMA Negeri 2 Boyolali tahun pelajaran 2015/2016.

\section{UCAPAN TERIMA KASIH}

Terima kasih peneliti ucapkan kepada Nur Heni Widyawati, S.Pd selaku guru mata pelajaran Kimia SMA Negeri 2 Boyolali, siswa kelas XI IPA 3 SMA Negeri 2 Boyolali serta seluruh pihak yang turut berperan dalam penelitian ini.

\section{DAFTAR RUJUKAN}

[1] Sanjaya, W. (2014). Strategi Pembelajaran. Jakarta: Kencana.

[2] Sanjaya, W. (2008). Kurikulum dan Pembelajaran. Jakarta: Kencana.

[3] Keenan, C.W., Kleinfelter, D.C., \& Wood, J.H. (1992). IImu Kimia untuk Universitas. Jakarta: Erlangga.

[4] Johnson, E. (2009). Contextual Teaching \& Learning Terj. Chaedar Alwasilah. Bandung: MLC.

[5] Hashemi, S.A. (2010). Science Production in Iranian Educational System by the Use of Critical Thinking. International Journal of Instruction, 3 (1), 61-76.

[6] Nezami, N.R., Asgari, M., \& Dinarvand, H. (2013). The Effect of Cooperative Learning On the Critical Thinking of High School Students. Technical Journal of Engineering and Applied Sciences, 3 (19), 25082514.

[7] Ariestika, I.A., Sedanayasa, M., \& Pudjawan, K. (2015). Penerapan Model Pembelajaran Kooperatif Tipe Teams Asisted Indiidualization (TAI) Berbantuan Lembar Kerja Siswa (LKS) Terstruktur Untuk Peningkatan Hasil Belajar 
Matematika. Jurnal Pendidikan Ganesha.

[8] Awofala, A.O.A., Arigbabu, A.A., Awofala, A.A. (2013). Effect of Framing and Team Asisted Individualised Instructional Strategies on Senior Secondary School Student' Attitudes Toward Mathematics. Acta Didactica Napocensia, 6 (1), 1-22

[9] Prastowo, A. (2012). Panduan Kreatif Membuat Bahan Ajar Inovatif. Yogyakarta: DIVA Press.

[10] Yildirim, N., Kurt, S., \& Ayas, A. (2011). The Effect of The Worksheets on Students' Achievement in Chemical Equilibrium. Journal of Turkish Science Education, 8 (3), 1-15.

[11] Arikunto, S, Suhardjono, \& Supardi. (2008). Penelitian Tindakan Kelas. Jakarta: Sinar Grafika.

[12] Miles, M., \& Huberman, A.M. (1992). Analisis Data Kualitatif. Jakarta: UI Press.

[13] Moleong, L.J. (2013). Metodologi Penelitian Kualitatif. Bandung: PT Remaja Rosdakarya. 